\title{
Temper Brittleness of Some Fe-Ni-Cr Alloys
}

\author{
by L. D. Jaffe
}

TN 1945-1946, the author measured temper brittle1 ness in ingots of varying composition prepared by remelting SAE 3135 bar stock under vacuum. Since other investigators ${ }^{1-3}$ have been referring to this hitherto unpublished work, belated publication seems worthwhile.

Steel in $7 \mathrm{lb}$ batches ${ }^{4}$ was induction melted with nickel additions in a magnesia crucible under a pressure of 10 microns of $\mathrm{Hg}$ or less and cast into a 2 in. diam chill mold. The compositions of ingots $A, B$, and $C$ prepared in this way are shown in Table I; the vacuum melting lowered carbon, manganese, sulphur, and nitrogen content. Ingot $B$ was homogenized $24 \mathrm{hr}$ at $1095^{\circ} \mathrm{C}$; ingots $A$ and $C$ were not homogenized. Blanks, $1 / 2$ in. square, were cut from each ingot, austenitized $1 \mathrm{hr}$ at $870^{\circ} \mathrm{C}$, water quenched, tempered $1 \mathrm{hr}$ at $595^{\circ} \mathrm{C}$, and water quenched. Half the blanks from each ingot were given an embrittling treatment of $50 \mathrm{hr}$ at $455^{\circ} \mathrm{C}$ and water quenched. A few specimens, embrittled and unembrittled, were finally heated $1 \mathrm{hr}$ at $580^{\circ} \mathrm{C}$ and water quenched.

Charpy specimens machined from the blanks were $V$-notched on the side closest to ingot mid-radius and paired as to radial position in the ingot, one of each pair having received the embrittling treatment and the other not. Specimens were broken in a standard impact machine at various temperatures, the same temperature, in general, being used for both bars of a pair. Fig. 1 shows the results. It is evident that temper brittleness, as measured by the increase in temperature of transition from brittle to tough failure introduced by the $455^{\circ} \mathrm{C}$ treatment, was decreased but not eliminated by reducing carbon to 0.006 pct, manganese to $<0.004$ pct, and nitrogen to 0.001 pct. In another study, ${ }^{\circ}$ temper brittleness was apparently eliminated by reducing carbon to 0.003 pet, with 0.80 pet $\mathrm{Mn}$ and 0.0015 pet $\mathrm{N}$ (ingot $D$ ).*

* Analyses given for carbon below 0.02 pct were made by Jensen method; for nitrogen, by Kjehldahl method. Values quoted elsewhere $1-8,5$ for carbon content of ingot $C$ and for nitrogen content uum fusion methods, respectively, and are considered much less accurate.

The $580^{\circ} \mathrm{C}$ final treatment removed previous embrittlement (ingot $B$ particularly), indicating that this was "reversible embrittlement.",

Metallographic examination of ingot $C$ with 1 pct nital etch revealed only ferrite; ingot $A$ had carbide spheroids uniformly distributed in a ferrite matrix. With ethereal picric acid plus zephiran chloride etchant, ${ }^{7}$ no differences between embrittled and un-

L. D. JAFFE, Member AIME, formerly associated with Watertown Arsenal, Watertown, Mass., is Chief, Materials Section, Jet Propulsion Laboratory, California Institute of Technology, Pasadena, Calif.

TN 255E. Manuscript, Feb. 2, 1954.
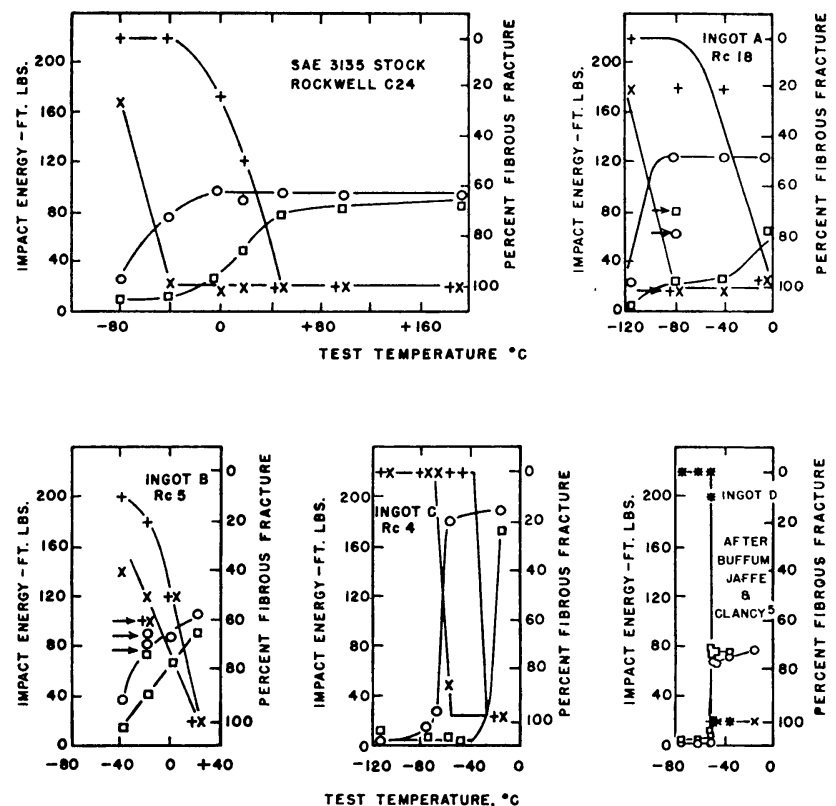

Fig. 1-Experimental data. Circle is impact energy, unembrittled; square, impact energy, embrittled; $X$, percent fibrous fracture, unembrittled; + , percent fibrous fracture, embrittled; and arrow designates specimens reheated to $580^{\circ} \mathrm{C}$ and water quenched.

embrittled specimens of ingots $A, B$, or $C$ were noted. Fracture of $C$ and $D$ below the transition temperature was predominantly transcrystalline, with traces of intercrystalline, in both embrittled and unembrittled conditions. The corresponding fracture of unembrittled $B$ was mixed transcrystalline and intercrystalline; of embrittled $B$, predominantly intercrystalline with some transcrystalline areas.

\section{Acknowledgment}

The efforts of J. C. Leschen, formerly of National Research Corp., in preparing the ingots are acknowledged with thanks.

\section{References}

${ }^{1}$ A. P. Taber, J. F. Thorlin, and J. F. Wallace: Trans. ASM (1950) 42, pp. 1033-1056.

${ }^{2}$ B. C. Woodfine: Journal Iron and Steel Institute (1953) 173, pp. 229-240.

${ }^{3}$ R. Hultgren and J. C. Chang: Trans. ASM (1954) 46, pp. 1298-1317.

${ }^{4}$ J. H. Hollomon, L. D. Jaffe, D. E. McCarthy, and M. R. Norton: Trans. ASM (1947) 38, pp. 807-847.

${ }^{5}$ D. C. Buffum, L. D. Jaffe, and W. P. Clancy: Trans. AIME (1949) 185, pp. 499-500; Journal of Metals (August 1949).

J. F. Libsch, A. E. Powers, and G. Bhat: Trans. ASM (1952) 44, pp. 1058-1075.

${ }^{7} \mathrm{~J}$. B. Cohen, A. Hurlich, and M. Jacobson: Trans. ASM (1947) 39, pp. 109-138.

Table I. Compositions, Pct; Balance Nominally Fe

\begin{tabular}{|c|c|c|c|c|c|c|c|c|c|c|c|c|c|c|c|c|}
\hline Heat & $\mathbf{C}$ & $\mathbf{M n}$ & Si & $\mathbf{s}$ & $\mathbf{P}$ & $\mathbf{C r}$ & $\mathbf{N I}$ & Mo & $\mathbf{v}$ & Al & $\mathbf{M g}$ & $\mathbf{S b}$ & $\mathbf{B}$ & $\mathbf{N}$ & $\mathbf{o}$ & $\mathbf{H}$ \\
\hline$\underset{\substack{\text { melting } \\
\text { stock }}}{3135}$ & 0.35 & 0.87 & 0.22 & 0.022 & 0.029 & 0.50 & 1.16 & 0.005 & 0.003 & 0.020 & - & - & 0.0005 & 0.005 & - & - \\
\hline
\end{tabular}

